\title{
Adopting novel ecosystems as suitable rehabilitation alternatives for former mine sites
}

\author{
David Doley and Patrick Audet
}

\begin{abstract}
The nature and extent of environmental disturbance associated with mining commonly entails completely new and challenging combinations of climate, lithology and landform. Consequently, the outcomes of ecological processes associated with the recovery or restoration of ecosystems cannot be predicted reliably from previously known associations between their physical and biological components. For radically disturbed sites, we propose that it is not practicable to aim for the restoration of historical ecosystems. However, hybrid (reversibly different) or novel (irreversibly different) ecosystems comprising new combinations of physical and biological components, including both native and non-native species, could provide levels of stability and functionality acceptable to all stakeholders and within feasible management regimes. We propose that limiting physical conditions of the landscape can be identified and managed, and that alternative species combinations for introduction to these new landscapes may be considered with cautious optimism.
\end{abstract}

Keywords: Natural ecological analogues; Novel ecosystems; Mining; Landscape suitability

\section{Review}

The goal for rehabilitation of mined land is often to restore the pre-disturbance land use or ecosystem (Queensland DEHP 2012), although different levels of biodiversity and ecosystem function can be negotiated between the mining proponent and regulator. In either case, it is commonly assumed that the essential physical resources assembled during the rehabilitation processnamely landform, lithology and soil-will closely resemble conditions of the pre-disturbance environment. While this assumption can be valid for certain degraded agricultural, forest or pastoral lands (Ferris et al. 2000; Chazdon 2008; Bullock et al. 2011; Tongway and Ludwig 2011), it may not be equally applicable to many mine sites, where there are radical changes to almost every component of the landscape as well as persistent nonnatural landscape features (e.g. open-pits, waste heaps) (Cooke and Johnson 2002; Bens and Hüttl 2005; Norman et al. 2006; Herath et al. 2009; Tozer et al. 2012). Since land rehabilitation becomes increasingly more difficult with increasing size and severity of the disturbance impact, many authors have justifiably questioned

\footnotetext{
* Correspondence: p.audet@uq.edu.au

Centre for Mined Land Rehabilitation, Sustainable Minerals Institute,

The University of Queensland, Brisbane (St. Lucia), QLD 4072, Australia
}

whether targeting historical and/or pre-disturbance ecosystems (i.e. "going back to the past") is always the most appropriate restoration goal in these post-industrial environments, particularly within the range of feasible biological and socioeconomic outcomes (Harris et al. 2006; Choi 2007; Seastedt et al. 2008). Yet, finding suitable alternatives which meet the needs of conservationists, practitioners and regulators in light of these unavoidable challenges remains elusive (Jackson and Hobbs 2009).

The degree to which disturbances cause ir/reversible changes to ecosystems provides direct insight into the likelihood of rehabilitation efforts either achieving near/ natural restoration versus developing hybrid systems (i.e. slightly different in form and function, yet sharing many attributes with the historical system) or even novel systems (i.e. new combinations of physical and biological attributes as a result of novel conditions within the postdisturbance environment) (refer to Endnote for details). This natural/novel ecosystems paradigm (pioneered by Hobbs et al. 2006) and associated terminology (now defined by Mascaro et al. 2013) are valuable for depicting the developmental pathways of a range of postdisturbance ecosystems and the management inputs required to re-instate (if practicable) the historical and/or pre-disturbance system (Figure 1). 


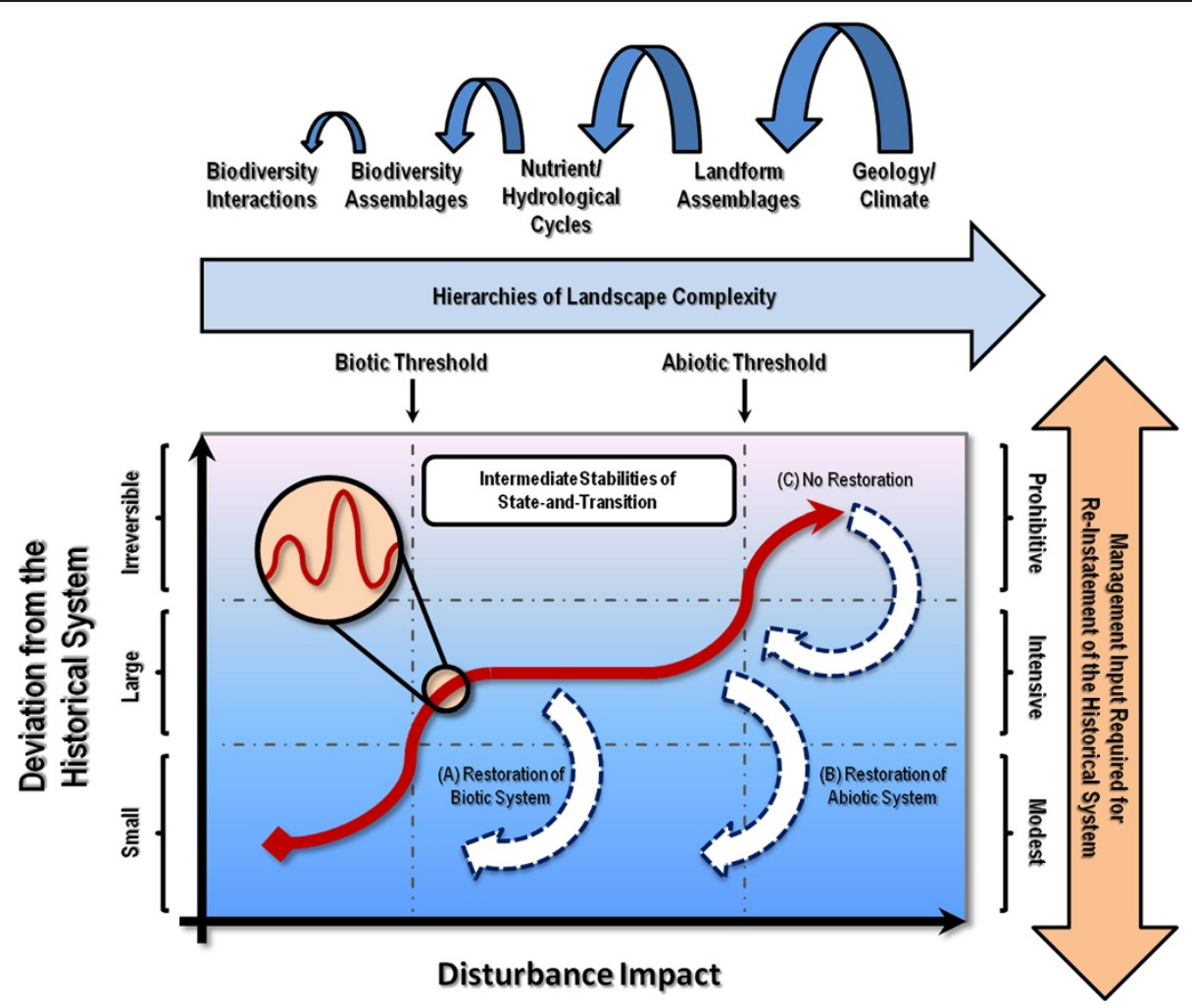

Figure 1 Intermediate stabilities of state-and-transition for ecosystems subjected to disturbance impacts of increasing size and severity (adapted from Hobbs and Suding 2009; Jackson and Hobbs 2009). Deviation from the historical system increases (from small to large to irreversible) as increassing hierarchies of landscape complexity are crossed, resulting in commensurate increases in management input (from modest to intensive to prohibitive) required for re-instatement of the historical system. Ir/reversibility of biotic and abiotic thresholds determines the likelihood of $(\mathbf{A})$ restoration of the biotic system, (B) restoration of the abiotic system, or (C) no restoration.

At the very least, this depiction recognizes potential barriers to achieving veritable restoration in relation to the requirements of rehabilitating landscape hierarchies of increasing complexity (e.g. biodiversity interactions < biodiversity assemblages < nutrient and/or hydrological cycles < landform assemblages < geology and climate). However, there has been some reluctance in approaching the rehabilitation of highly assertive anthropogenic activities from a similar perspective, possibly out of fear of lowering rehabilitation standards (see Perring et al. 2013 in this issue). This apprehension is especially acute regarding those lucrative industries, such as mining, that have drastic environmental impacts that impose high ecological liabilities and whose post-disturbance landscapes have so few parallels in the natural realm (Foster et al. 1998).

Doley et al. (2012) recently examined this dilemma within the Australian context for post-mining land rehabilitation and derived a framework (Figure 2) to reconcile natural/ novel ecosystems theory (Hobbs et al. 2006, 2013) with existing guidelines for land rehabilitation (e.g. Australia DIRT 2006). Here, possible development pathways of postmining landscapes were identified in relation to the severity of the disturbance impact and the design of rehabilitation approaches. Ecological and socio-economic scenarios were then described that extend the definition of novel ecosystems to the endpoints of mine site rehabilitation. In brief, it was proposed that, where both the abiotic and biotic systems are significantly and irreversibly affected, the carefully planned installation of alternative (managed) ecosystems or novel (unmanaged) ecosystems could represent achievable and predictable options for highly degraded, underrehabilitated and/or derelict mine sites. A key advantage of this approach was that commitments to rehabilitation could be assessed and adjusted ad hoc based on the characteristics and limiting capacities of the post-disturbance landscape, while also providing opportunities for the incorporation of, e.g., novel ecosystem services and enhanced land-use value otherwise not found within the historical or pre-disturbance ecosystem (Bullock et al. 2011). A pre-condition of this adaptive management approach is that all stakeholders (operator, regulator and community) are involved in setting and accepting the parameters for decision-making.

Albeit useful as a conceptual framework, this scheme cannot yet contribute optimally to the planning of mined land rehabilitation by operators and regulators unless 


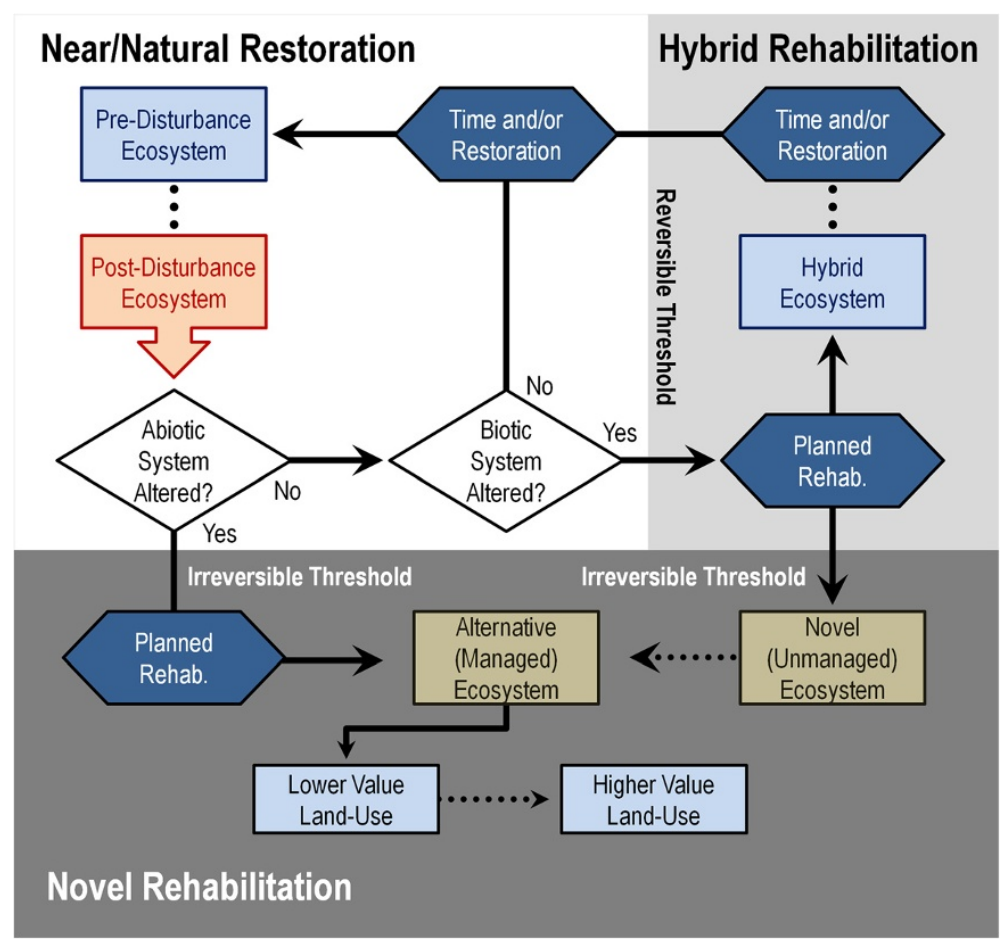

Figure 2 Natural/novel ecosystems paradigm. Conceptual flow chart for the development of restored near/natural ecosystems, rehabilitated hybrid ecosystems, and rehabilitated alternative (managed) and novel (unmanaged) ecosystems. The likely development pathways of post-mining landscapes were identified by comparing the planned severity of the disturbance impact and associated rehabilitation design (according to Doley et al. 2012) to which the notions of threshold ir/reversibility have now been added to distinguish between the respective domains of near/ natural, hybrid and novel ecosystems (according to Hallett et al. 2013). Notably, in this scheme, it is assumed that mining disturbances resulting in the crossing of abiotic thresholds also necessarily result in the crossing of biotic thresholds. While this may not be the case universally, our pathway primarily leads directly to novel outcomes. Refer to the Endnote for definitions of near/natural, hybrid and novel ecosystems relating to threshold ir/reversibility within the post-disturbance environment.

objective descriptors can be used to determine the degree to which post-disturbance ecosystems may be considered natural or novel-and then to derive suitable management responses for such conditions. Hence, this analysis presents elements of landscape suitability (e.g. Tongway and Ludwig 2011) and biological condition assessments (e.g. Eyre et al. 2011) that may enable a choice regarding the development of post-mining ecosystems towards achievable rather than aspirational rehabilitation goals (Figure 3). Whether these outcomes are deemed to be natural or novel, we emphasize that the primary outcomes should always aim to achieve the highest standards of biological conservation and ecosystem stewardship.

\section{Setting mine site rehabilitation goals based on post-disturbance landscape assessments}

The commonly used practice of nominating a particular vegetation association as an end-goal for land rehabilitation assumes that all of the required pre-disturbance attributes Table 1 can be reinstated. Indeed, this strategy provides a range of standardized criteria (e.g. biodiversity, structure, function) which could be used to monitor the trajectories of post-disturbance ecosystems toward desired reference communities. However, it is not clear that these conditions would be satisfied on many mine sites due to the size and severity of the mining disturbance, thereby putting into doubt whether achieving veritable restoration is at all possible. This could account (in part) for some of the onerous and often costly procedures required when applying conventional restoration approaches (usually reserved for less assertive disturbance impacts) to highly disturbed post-mining environments (Gardner and Bell 2007; Koch 2007). For these reasons, mined land rehabilitation planning would benefit from the identification of attainable condition descriptors of post-disturbance landscapes and a careful delineation of the range of ecosystems that may be established under these conditions. With this general approach, a decision tree (i.e. best supported by large datasets) can summarize the tests that identify conditions for restoration (sensu Hobbs et al. 2013) and also the optimal management responses in cases where hybrid and novel ecosystems could represent more practicable rehabilitation outcomes (Figure 2). 


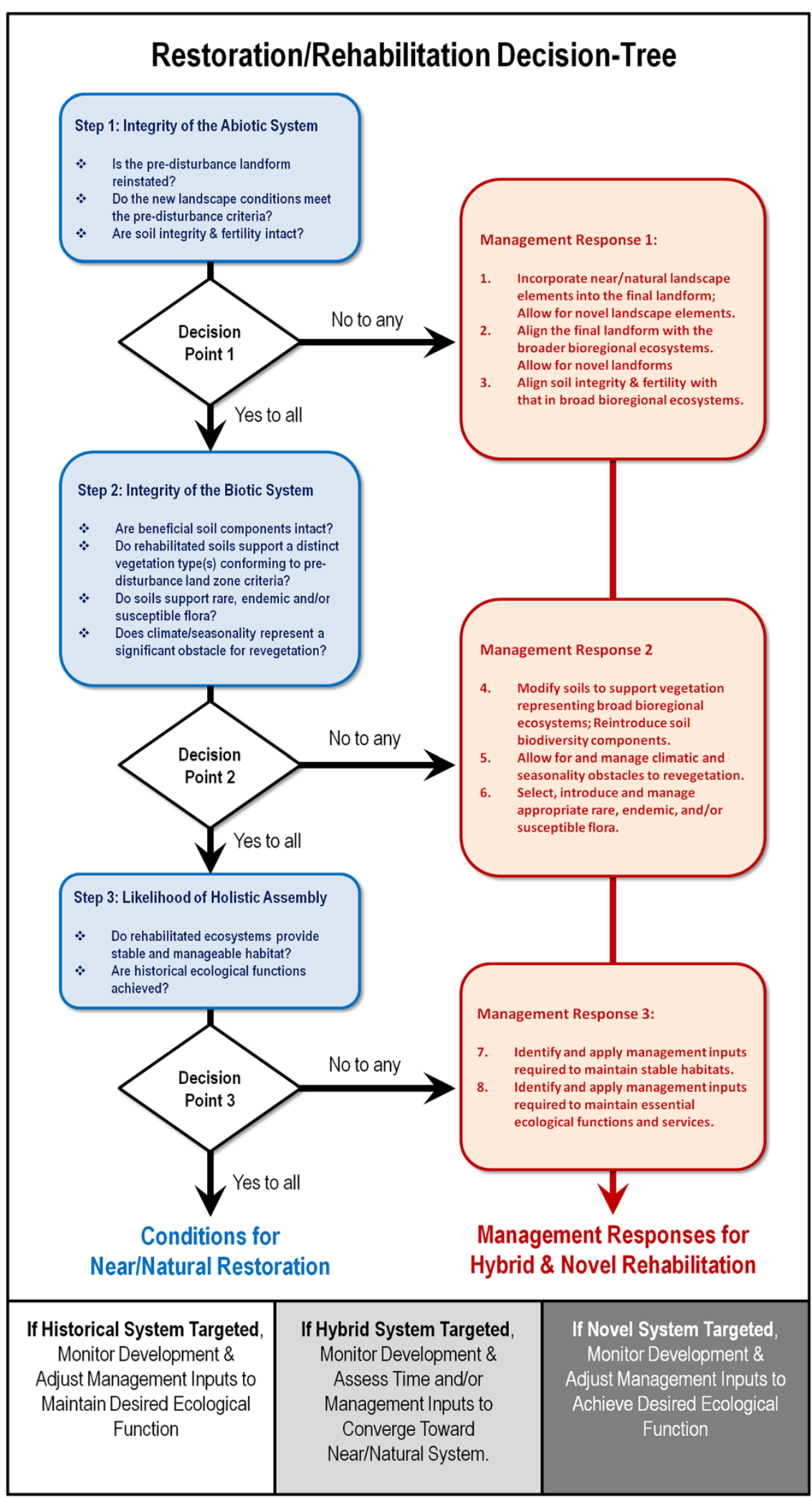

Figure $\mathbf{3}$ (See legend on next page.) 
(See figure on previous page.)

Figure 3 Restoration/rehabilitation decision tree for post-mining environments. Conditions, requirements and likely management responses for near/natural restoration vs. the development of hybrid or novel systems used to inform Figure 1. Responses to decision points distinguish between the likelihood of achieving near/natural restoration vs. hybrid or novel systems. Refer to the Endnote for definitions of near/ natural, hybrid and novel ecosystems relating to threshold ir/reversibility within the post-disturbance environment.

\section{Is the abiotic system altered?}

\section{Significance of climate, geology and landform}

Climate is a major determinant of vegetation development (Harris et al. 2006)-particularly in reconstructed environments (Audet et al. 2012) - and recent warming has displaced latitudinal ranges of some species by about $17 \mathrm{~km}$ per decade (Chen et al. 2011). However, these climatic changes are likely to be overshadowed by radical changes in the states of land zones (degree of consolidation, origin and geomorphology), all of which hierarchically influence ecosystem patterns and processes for a given vegetation type (Sattler and Williams 1999). Within each bioregion, regional ecosystems (REs) are defined by some government conservation agencies as native vegetation communities consistently associated with particular combinations of land zone and soil (Sattler and Williams 1999). Notably, some variation in species composition of the vegetation community can be accommodated by a single RE, and mixing of REs may be recognized (Neldner et al. 2012). The scale at which REs are mapped is influenced by the activities under consideration, whereby high intensity activities such as mine site rehabilitation may require a resolution of $1: 20,000$ or 1:25,000 (0.8-1.7 ha) (Neldner et al. 2012). At these scales, relatively fine details of land form together with the lithology and pedology of a reconstructed site can be determined accurately (Tongway and Ludwig 2011). Meanwhile, land surveys can discriminate more subtle differences in landform so that assessment of a target vegetation community could be tempered by local variations in land capability (Tongway and Ludwig 2011). With this information, a critical first-step for mine site rehabilitation is to consider the following questions (cf. Figure 2):

- Is the pre-disturbance landform reinstated?

- Does the new landscape condition meet the pre-disturbance criteria?

- Are soil integrity and fertility intact?

Based on these criteria, the historical REs could be used as targets for rehabilitation only if the post-disturbance landscape units are judged by the environmental regulator to bear a reasonable physical resemblance to these environments. Such conditions may occur when a relatively thin layer of material is removed (bauxite mining; Koch 2007) or the bulk of the material can be returned without drastic physical or chemical alteration (sand mining; Smith and
Nichols 2011). Reports on the progress and success of mine rehabilitation in Australia are relatively sparse and unevenly distributed (Cristescu et al. 2012). However, successful mine lease extinguishment has followed the attainment of completion criteria in a bauxite mine in Western Australia (Gardner and Bell 2007), and progress towards this goal has been recorded in Australia for other bauxite mines (Gould 2011, 2012; Tongway and Ludwig 2011) and sand mines (Herath et al. 2009; Gravina et al. 2011; Smith and Nichols 2011).

When selecting between natural or novel rehabilitation outcomes, this RE approach assumes that geomorphological processes will have resulted in a land surface with a relatively predictable pattern of variation in soil characteristics (cf. Table 1), resulting in a predictable vegetation community (Burgess 2003). If quantitative comparison of the abiotic characteristics of the disturbed landscape and that of the known historical RE (predicted or extant) do not correspond within defined limits (Burgess 2003; Tongway and Ludwig 2011), it may be necessary to consider an alternative or hybrid vegetation association for establishment on that land unit-preferably one that incorporates multiple components from the historical landscape while also accommodating potentially novel or non-natural elements (e.g. waste rock heaps and open pits) based on landform components found within the RE. Ideally, pre-mine planning (Warhurst and Noromba 2010) would predict the range of landforms and lithologies that could be assembled in the final landscape to ensure that the rehabilitation outcome aligns as closely as possible with the essential function and attributes found nearby or more broadly within the RE (Worrall et al. 2009). By definition, further rehabilitation inputs invested over time could facilitate the restoration of pre-disturbance landform criteria among hybrid ecosystems; however, this goal cannot be claimed for novel ecosystems given the irreversible crossing of abiotic thresholds (Hobbs et al. 2013). Nevertheless, the approach would still be conducive to the development of rehabilitated ecosystems bearing features and capabilities similar to those found within the broader bioregional mosaic.

\section{Is the biotic system altered? Influence of soils}

Once essential landform elements are reconstructed, typical rehabilitation schemes assume that the physical requirements for the development of a desired vegetation type could be assembled almost immediately after the 
Table 1 Hierarchies of site information for analyses of functional landscapes ${ }^{\dagger}$

\begin{tabular}{|c|c|c|c|c|}
\hline & Factor & Attribute & Physical property & \\
\hline \multirow[t]{16}{*}{ Is the abiotic system altered? } & \multirow[t]{4}{*}{ Geology* } & 1. Consolidation & & \\
\hline & & 2. Origin & & \\
\hline & & 3. Mineralogy & & \\
\hline & & 4. Texture & & \\
\hline & \multirow{12}{*}{ Landscape } & \multirow{6}{*}{ 1.Form } & \multicolumn{2}{|l|}{ a. Landform class } \\
\hline & & & \multicolumn{2}{|l|}{ b. Landform pattern } \\
\hline & & & \multicolumn{2}{|l|}{ c. Landform element } \\
\hline & & & \multirow[t]{3}{*}{ d. Quantitative attributes } & i. Relief \\
\hline & & & & ii. Slope \\
\hline & & & & iii. Texture \\
\hline & & \multirow{6}{*}{ 2. Function } & \multirow[t]{2}{*}{ a. Surface } & i. Erosion \\
\hline & & & & i. Deposition \\
\hline & & & \multirow[t]{4}{*}{ a. Profile } & i. $\mathrm{pH}$ \\
\hline & & & & i. EC \\
\hline & & & & i. nutrient status \\
\hline & & & & ii. water status \\
\hline \multirow[t]{11}{*}{ Is the biotic system altered? } & \multirow{7}{*}{ Vegetation } & \multirow{3}{*}{ 1. Structure } & \multicolumn{2}{|l|}{ a. Height } \\
\hline & & & \multicolumn{2}{|l|}{ b. Cover } \\
\hline & & & \multicolumn{2}{|l|}{ c. Biomass } \\
\hline & & & \multicolumn{2}{|l|}{ a. Species richness } \\
\hline & & 2. Composition & \multicolumn{2}{|l|}{ b. Diversity } \\
\hline & & & \multicolumn{2}{|l|}{ c. Structural class } \\
\hline & & 3. Condition & & \\
\hline & \multirow{2}{*}{ Soil biota } & 1. Abundance & & \\
\hline & & 2. Diversity & & \\
\hline & \multirow{2}{*}{ Fauna } & 1. Abundance & & \\
\hline & & 2. Diversity & & \\
\hline
\end{tabular}

Note: *Geology and biochemistry of the parent material including, e.g., tailings and spoils.

${ }^{\dagger}$ From Doley et al. (2012); adapted from Tongway and Ludwig (2011).

disturbance has ceased (Australia DIRT 2006). For example, the replacement of retained bioactive topsoil (containing indigenous seeds and beneficial microbes) on reconstructed landscapes has been shown to facilitate the reestablishment of native and/or keystone vegetation and the reinstatement of pre-existing REs (Bell 2001; Queensland DEHP 2012). Such rehabilitation has been successful following mineral sand mining on the south-eastern coast of Queensland Australia (Smith and Nichols 2011) and bauxite mining in Western Australia (Gardner and Bell 2007; Koch 2007; Grant 2009; Tongway and Ludwig 2011) in which the biogeochemical composition of the post-disturbance landform and substrates was not significantly different from the predisturbance conditions. Outside of these examples, the reshaping of the landscape and disturbance of topsoil is likely to have different ecological consequences depending on the underlying landform and lithology due to both obvious and subtle losses of matrix structure and reductions in nutrient status and microbial viability (Cooke and Johnson 2002;
Bradshaw 2004; Bens and Hüttl 2005; Banning et al. 2012). Therefore, commensurate changes may be required in the identification of target vegetation associations where there is a fundamental change in both the physical and chemical attributes of a land unit. These circumstances give rise to questions relating to the post-mining environment (cf. Figure 2):

- Are beneficial soil components intact?

- Do rehabilitated soils support a distinct vegetation type(s) conforming to pre-disturbance land zone criteria?

- Do soils support rare, endemic or environmentally sensitive flora?

- Does climate/seasonality represent a significant obstacle for revegetation?

Critical abiotic properties with significant impacts on the biotic system being rehabilitated are the propensity 
of the site for erosion, the amount of plant available water in the rooting zone, soil $\mathrm{pH}$, fertility and salinity (Schmidt et al. 1999; Schneider et al. 2010). As described previously, if the soil characteristics of the reconstructed site cannot be specified closely, the specification of the vegetation association cannot be very precise. The difficulty of such prediction can be demonstrated by considering a very detailed soil and vegetation analysis carried out over 300,000 ha in central Queensland, Australia (Burgess 2003), the setting for intensive mining of coal (and coal-seam gas), gold, silver, limestone, magnesite and gemstones. Sixty-nine soil profile types were identified on landscapes ranging from steep slopes to flat clay pans and flood plains derived from igneous, metamorphic and sedimentary rock types. In the central Queensland environment where evaporation exceeded rainfall, one of the major limitations to plant survival was salinity, and many of the soils were dispersive on account of high sodium contents so they were prone to erosion. The first requirement for post-mining sites is that they be safe, stable and non-polluting (Queensland DEHP 2012). In many mining situations, the resulting landform properties (cf. Table 1) may have predictable surface and soil characteristics that may be associated with vegetation associations that are different from the historical and are potentially novel. If the rehabilitated environment is required to support a particular historical vegetation type, then appropriate actions (such as modifying fertility and moisture parameters) must be taken to bridge the gap between the characteristics of the post- and pre-disturbance environments. These actions may require decades and extensive management inputs for completion, so identification of realistic and achievable end-points is necessary to account for changes in rehabilitation planning.

\section{Is the biotic system altered? Influence of vegetation}

Another matter for consideration is the manner in which vegetation types coexist on multiple soil types. In central Queensland, Burgess (2003) described 42 vegetation associations according to the procedures described by Neldner et al. (2012) covering sufficiently large areas to be analyzed. For all of the 69 soil profile types, there was no unique association with a given vegetation type, but between two and six vegetation associations could be found on any soil profile type. Where one soil type was examined at more than one location, the dominant vegetation association sometimes differed between locations. This variation could indicate that there is a stochastic component to the occurrence of vegetation on soil types or that subtle changes in vegetation associations are the result of the separation of localized niches for different species (Austin et al. 2009) that are not related to the variables assessed by Burgess (2003). It also underlines the practicality of mixed RE categories at broad mapping scales for setting rehabilitation goals (Neldner et al. 2012) compared to the common strategy of targeting a particular soil-vegetation assembly and perhaps relatively narrow rehabilitation outcomes. If specific vegetation associations are identified for replacement in particular landform elements, it must be assumed that the necessary physical conditions can be provided. Where these assumptions cannot be met, different vegetation associations might be expected to occur regardless of the nature of the topsoil that is spread over the substrate.

In view of the sometimes pronounced differences in vegetation associations that occur with relatively small differences in soil profile type (Audet et al. 2013), rehabilitation contract conditions that require the establishment of only local ecotypes of pre-existing species on a reconstructed landscape may not be fulfilled. Species selection could be based on scenario modelling of landscape function analysis (Guisan and Zimmermann 2000; Tongway and Ludwig 2011) and the identification of functional groups that are most likely to survive in the new conditions (Grant et al. 2002; Bradshaw 2004; Wagner 2004), particularly to allow for climatic and seasonality obstacles to revegetation. It may be necessary to compromise local biodiversity in order to achieve stable vegetation cover by early introduction of the major structural and functional components of vegetation associations that might be expected to survive in the postdisturbance abiotic environment (Koch 2007). A consequence of this would be that a broad list of species from the bioregion should be tested for incorporation in rehabilitation procedures, including fast growers vs. slow growers, or native vs. non-native species (Shackelford et al. 2013a). This would require a change in perceptions since the criteria for assessment of the success of species establishment might be based first on ecological function analysis (Tongway and Ludwig 2011), second on biodiversity criteria (Eyre et al. 2011), and third on a commitment to timely management intervention based on ecosystem developmental trajectories as well as final target outcomes (Grant 2006, 2009; Shackelford et al. 2013b).

\section{Are desired ecosystem characteristics achieved? Requirements for ecological services}

The final component of our decision tree refers to the condition requirements for maintaining or reinstating and managing natural ecological disturbance regimes. In an Australian context, this means optimizing the effects of fire and mitigating the effects of weeds, pests and seasonal conditions on both vegetation and fauna (Hobbs 2004; Chazdon 2008; Bullock et al. 2011). In short, this task inquires of the rehabilitated ecosystems (cf. Figure 2): 
- Do rehabilitated ecosystems provide stable and manageable habitat?

- Are historical ecosystem functions achieved?

Ecosystem stability is defined as variation in structure and condition (Eyre et al. 2011) within the historical range of variability (Suding and Hobbs 2009), and a manageable habitat is defined as that which can be maintained in a stable condition by intervention that is both practical and economical (Grant 2006). Unfortunately, there are no general or rapidly applied indicators of stability for novel ecosystems due not only to the potentially complicated and site-specific requirements for ecosystem assembly (Koch 2007; Bullock et al. 2011; Tongway and Ludwig 2011), but also to the fluid socioeconomic boundaries typically associated with postmining land rehabilitation (Gardner and Bell 2007; Worrall et al. 2009; Warhurst and Noromba 2010; Smith and Nichols 2011). Compared with the costs of land preparation for most other rural industries, mined land rehabilitation is expensive, even for sites such as bauxite mines, where disturbance is relatively limited (Gardner and Bell 2007). In addition, resource limitations (e.g. lack of topsoil, toxicity or salinity of substrate) often limit the extent to which the historical ecosystem conditions can be approached (Grant et al. 2002; Madsen and Mulligan 2006).

Expectations for highly disturbed (and lucrative) mining activities are that rehabilitated ecosystems should recover relatively soon after the disturbance and in proportion to investment of resources, often regardless of the size and severity of the disturbance (Australia DIRT 2006). Paradoxically, because soil and subsurface properties may be changed radically, rehabilitation success can only be assessed effectively over longer timelines and preferably using multiple ecological indicators and endpoints (e.g. Block et al. 2001; Nichols and Nichols 2003; Craig et al. 2012; Williams et al. 2012; Critescu et al. 2013; Majer et al 2013). The determination of the stability of novel or alternative ecosystems is one activity for which adaptive management may be most appropriate. Part of this management process would be the development and refinement of quantitative indicators of site and ecosystem condition. Convergence of rehabilitated environments toward target ecosystems is most likely to occur where physicochemical alteration of the substrate has been limited, the climate has suitable temperatures and distribution of rainfall, and the soil-surface conditions are favorable or may improve over time (Norman et al. 2006; Koch 2007; Smith and Nichols 2011; Audet et al. 2012). Rehabilitation efforts can then be focused on facilitating conditions in support of stable habitat and manageable ecological regimes, e.g. integration of seasonal fire (Grant et al. 2007) and/or low intensity grazing (Tongway and Ludwig 2011; Firn et al. 2013 in this issue). However, where the post- disturbance environment has an altered nutritional status and/or contains seeds of less desirable species (e.g. exotic or selected pasture grasses), repeated attempts at introducing natural ecological regimes may fail and even cause further divergent outcomes (Tongway and Ludwig 2011). It then follows that restoration of natural ecological regimes and habitat would remain incomplete or in a state of arrested development if left unmanaged (Grant 2006, 2009). Meanwhile, truly hybrid or novel site conditions may not have ecosystem characteristics that have been previously described, other than those which can be predicted from the broader RE.

For these reasons, we suggest that rehabilitation goals for highly disturbed areas such as mine sites should be set by agreement among the industry, regulator and relevant stakeholders at the highest feasible level (e.g. the pre-disturbance RE) - as envisaged in the New Zealand Resource Management Act (Pokhrel and Dubey 2012) but should allow for adjustment of the goal in the light of circumstance (Worrall et al. 2009). Each agreed change of goal should be preceded by a thorough and objective analysis of the physical environmental and socioeconomic conditions (Pokhrel and Dubey 2012), so that the highest attainable environmental outcomes are delivered.

Many studies have been carried out on the suitability of mine sites for the early establishment of vegetation (e.g. Bell and Bellairs 1992; Huxtable et al. 2005; Madsen and Mulligan 2006; Courtney and Mullen 2009) and the subsequent outcomes of rehabilitation (Mulligan 1996; Menzies and Mulligan 2000; Koch 2007; Gravina et al. 2011; Vickers et al. 2012). Therefore, determining the range of predictable outcomes for hybrid or novel ecosystems can be achieved based on properties found naturally in broader REs. However, apart from reports on fire and tree thinning (Koch 2007; Craig et al. 2010) and microhabitat management (Christie et al. 2013) in rehabilitated bauxite mines in Western Australia, there are few accounts of the longer term ecological and associated site management processes that may be involved. In order to avoid compromising higher standards of rehabilitation, a careful and cautious approach based on the best available data should be applied when determining the range of vegetation types most suitable for a given soil and vegetation classification, followed closely by appropriate management inputs required to maintain stable habitats and ecological function.

\section{Conclusions}

Rehabilitation of highly disturbed landscapes such as mine sites may not provide realistic opportunities for the ecological processes normally associated with ecosystem recovery to occur. Consequently, it may be more 
helpful to put aside theoretical considerations of ecosystem development to focus on the pragmatic requirement of securing conditions that are safe, stable and nonpolluting, and that provide suitable environments for vegetation establishment and ultimately habitat development. The target ecosystems may be quite different from those that occupied the site prior to disturbance, and they may be difficult to discern at the planning stage of a mining operation. This lack of a clear rehabilitation goal necessitates careful analysis of the available evidence at each stage of planning and operations, and a willingness and capacity to adjust goals according to the best practice that can be achieved with the expectation that it will be overtaken in the future by something better.

The fact that some mine leases have been relinquished indicates that successful rehabilitation is possible. The fact that the number of abandoned, pending, dormant or inactive leases exceeds the number that have been relinquished shows that the path to mine site rehabilitation is not smooth or direct. We consider that the first requirement for rehabilitation is a careful analysis of the physical environment, followed by the identification and consideration of possible amelioration treatments, and the progressive development of a manageable final landscape-this, no matter whether it is defined as being natural, hybrid or novel. Regardless of the final landscape, we conclude that it will not become self-managing but will always require some intervention, ideally minimizing resource requirements while optimizing resource outputs or ecosystem services. Successful rehabilitation management depends on a continual increase in understanding of the system under management and an ability and willingness on the part of all stakeholders to achieve the optimum ecosystem outcomes.

\section{Endnotes}

The definition of ecosystem conditions associated with disturbance and recovery has been clarified greatly by Hobbs et al. (2013) and has evolved over a decade of consideration regarding assembly rules (Temperton et al. 2004) and the desirability of identifying stable ecosystems that are different from those pre-dating the disturbance (Hobbs and Norton 1996; Hobbs and Suding 2009; Hobbs et al. 2009) and that may be described as novel (Hobbs et al. 2006, 2009) or alternative to historical ecosystems (Cale and Willoughby 2009). The terms used here derive from Mascaro et al. (2013) referring to ecosystems that are not: "(1) a [historical ecosystem] that would have occupied that space in the past (i.e. part of a historical range of variability); (2) a system managed intensively for specific production or built over; or (3) a [hybrid ecosystem] managed with the purpose of reproducing the historical ecosystem (i.e. classic restoration)." Central to this concept is the nature of thresholds between ecological states
(Hobbs et al. 2009; Suding and Hobbs 2009), and whether transition across a threshold is reversible or not. Crucially, Hobbs et al. (2013) have proposed that novel ecosystems are an outcome of irreversible transfer across abiotic or biotic thresholds. Within a novel ecosystem, it is possible to have either biotic or abiotic conditions that are very similar to those of a historical ecosystem; however, restoration cannot be claimed to have occurred unless both abiotic and biotic conditions are sufficiently similar to those of a historical ecosystem. In order to guide activities on intensively managed lands, the goals of restoration or rehabilitation need to be clarified and, where possible, quantified; especially the feasibility of attaining a particular restoration or rehabilitation goal (Choi 2007; Bullock et al. 2011). As emphasized here, the same conditions apply perhaps even more forcefully to severely disturbed lands such as mine sites.

\section{Glossary of ecological terms}

Restoration Intentional activity that initiates or accelerates the recovery of an ecosystem with respect to its health, integrity and sustainability.

Historical Variation in ecosystem state that is within the historical range of variability.

Hybrid Ecosystem state within which an ecosystem is modified from the historical state by moderate and reversible changes to characteristics involving loss or addition of species (biotic) and/or land use change (abiotic).

Novel Ecosystem state within which systems have potentially been changed irreversibly by large modification to abiotic conditions (climate, geology, landform or land use) and/ or biotic composition (loss of existing species or addition of invasive species).

Reversible A limiting ecosystem state at which a tranthreshold sition to a different state is possible with practicable management inputs.

Irreversible A limiting ecosystem state at which a tranthreshold sition to a different state is not possible without the application of large and possibly impracticable management inputs.

Stability Variation in structure and condition within the historical range of variability.

Manageable One that can be maintained in a stable conecosystem dition by intervention that is both practical and economical.

\section{Competing interests}

Both authors declare that they have no competing interests with regard to any of the reported findings.

\section{Authors' contributions}

DD and PA contributed equally to the conceptualization, drafting and final revision of the manuscript. All authors read and approved the final

manuscript. 


\section{Acknowledgments}

The authors wish to thank the two anonymous reviewers and Guest-Editor (M Perring) for their beneficial commentary which contributed highly to improving this manuscript for publication. Special thanks are also extended to M Perring and RJ Hobbs for providing early access to the compilation book Novel ecosystems: Intervening in the new ecological world order by RJ Hobbs, ES Higgs and CM Hall (eds). This study was made possible by funding to P.Audet from The University of Queensland and the Natural Sciences and Engineering Research Council (NSERC) of Canada.

Received: 22 February 2013 Accepted: 25 June 2013

Published: 11 July 2013

\section{References}

Audet P, Arnold S, Lechner AM, Mulligan DR, Baumgartl T (2012) Climate suitability estimates offer insight into fundamental revegetation challenges among post-mining rehabilitated landscapes in eastern Australia. Biogeosci Discuss 9:18545-18569

Audet P, Gravina A, Glenn V, McKenna P, Vickers H, Gillespie M, Mulligan D (2013) Structural development of vegetation on rehabilitated North Stradbroke Island: Above/belowground feedback may facilitate alternative ecological outcomes. Ecol Process 2:20

Austin MP, Smith TM, Van Niel KP, Wellingron AB (2009) Physiological responses and statistical models of the environmental niche: a comparative study of two co-occurring Eucalyptus species. J Ecol 97:496-507

Australia DIRT (2006) Department Industry, Resources and Tourism. , Canberra

Banning NC, Lalor BM, Cookson WR, Grigg AH, Murphy DV (2012) Analysis of soil microbial community level physiological profiles in native and post-mining rehabilitation forest: which substrates discriminate? Appl Soil Ecol 56:27-34

Bell LC (2001) Establishment of native ecosystems after mining-Australian experience across diverse biogeographic zones. Ecol Engin 17:179-186

Bell DT, Bellairs SM (1992) Effects of temperature on the germination of selected Australian native species used in the rehabilitation of bauxite mining disturbances in Western Australia. Seed Sci Tech 20:47-55

Bens O, Hüttl RF (2005) Soil consumption through opencast lignite mining and ecological development potentials of anthropogenetically disturbed sites-a case study Lusatia coalfields, Germany. Die Erde 136:79-96

Block WM, Franklin AB, James P, Ward J, Ganey JL, White GC (2001) Design and implementation of monitoring studies to evaluate the success of ecological restoration on wildlife. Restor Ecol 9:293-303

Bradshaw AD (2004) The role of nutrients and the importance of function in the assembly of ecosystems. In: Temperton VM, Hobbs RJ, Nuttle T, Halle S (ed) Assembly rules and restoration ecology. Island Press, Washington, DC, USA, pp 325-340

Bullock JM, Aronson J, Newton AC, Pywell RF, Rey-Benayas JM (2011) Restoration of ecosystem services and biodiversity: conflicts and opportunities. Trends Ecol Evol 25:541-549

Burgess JW (2003) Land resource assessment of the Windeyers Hill area, IsaacConnors and Mackenzie River catchments, central Queensland. Land Resources Bulletin QNRM02189, vol. 1. Department of Natural Resources and Mines, Queensland

Cale P, Willoughby N (2009) An alternative stable state model for landscape-scale restoration in South Australia. In: Hobbs RJ, Suding K (ed) New models for ecosystem dynamics and restoration. Island Press, Washington DC, USA, pp 295-310

Chazdon RL (2008) Beyond deforestation: restoring forests and ecosystem services on degraded lands. Science 320:1458-1460

Chen IC, Hill JKJ, Ohlemüller R, Roy DB, Thomas CD (2011) Rapid range shifts of species associated with high levels of climate warming. Science 333:1024-1026

Choi YD (2007) Restoration ecology to the future: a call for new paradigm. Restor Ecol 15:351-353

Christie K, Stokes VL, Craig MD, Hobbs RJ (2013) Microhabitat preference of Egernia napoleonis in undisturbed jarrah forest, and availability and introduction of microhabitats to encourage colonization of restored forest. Restor Ecol. doi:10.1111/rec.12002

Cooke JA, Johnson MS (2002) Ecological restoration of land with particular reference to the mining of metals and industrial minerals: a review of theory and practice. Environ Rev 10:41-71

Courtney R, Mullen G (2009) Use of germination and seedling performance bioassays for assessing revegetation strategies on bauxite residue. Water Air Soil Pollut 197:15-22
Craig MD, Hobbs RJ, Grigg AH, Garkaklis MJ, Grant CD, Fleming PA, Hardy GESJ (2010) Do thinning and burning sites revegetated after bauxite mining improve habitat for terrestrial vertebrates? Restor Ecol 18:300-310

Craig MD, Hardy GESJ, Fontaine JB, Garkakalis MJ, Grigg AH, Grant CD, Fleming PA, Hobbs RJ (2012) Identifying unidirectional and dynamic habitat filters to faunal recolonisation in restored mine-pits. J Appl Ecol 49:919-928

Cristescu RH, Frère C, Banks PJ (2012) A review of fauna in mine rehabilitation in Australia: current state and future directions. Biol Conserv 149:60-72

Critescu RH, Rhodes J, Frére C, Banks PB (2013) Is restoring flora the same as restoring fauna? Lessons learned from koalas and mining rehabilitation. J Appl Ecol 50:423-431

Doley D, Audet P, Mulligan DR (2012) Examining the Australian context for postmined land rehabilitation: reconciling a paradigm for the development of natural and novel ecosystems among post-disturbance landscapes. Agric Ecosys Environ 163:85-93

Eyre TJ, Kelly AL Neldner VJ, Wilson BA, Ferguson DJ, Laidlaw MJ, Franks AJ (2011) BioCondition: a condition assessment framework for terrestrial biodiversity in queensland. Assessment manual, version 2.1. Department of Environment and Resource Management (DERM), Biodiversity and Ecosystem Sciences, Brisbane

Ferris R, Peace AJ, Humphrey JW, Broome AC (2000) Relationships between vegetation, site type and stand structure in coniferous plantations in Britain. Forest Ecol Manag 136:35-51

Firn J, Price JN, Whalley RDB (2013) Using strategically applied grazing to manage invasive alien plants in 'novel grasslands'. Ecol Process. \#5611084989937423 (accepted)

Foster DR, Knight DH, Franklin JF (1998) Landscape patterns and legacies resulting from large, infrequent forest disturbances. Ecosystems 1:497-510

Gardner JH, Bell DT (2007) Bauxite mining restoration by Alcoa World Alumina Australia in Western Australia: social, political, historical, and environmental contexts. Restor Ecol 15(Suppl):S3-S10

Gould SF (2011) Does post-mining rehabilitation restore habitat equivalent to that removed by mining? A case study from the monsoonal tropics of northern Australia. Wild Res 38:482-490

Gould SF (2012) Comparisons of post-mining rehabilitation with reference ecosystems in monsoonal eucalypt woodlands, northern Australia. Restor Ecol 20:250-259

Grant CD (2006) State-and-transition successional model for bauxite-mining rehabilitation in the jarrah forest of Western Australia. Restor Ecol 14:28-37

Grant CD (2009) State-and-transition models for mining restoration in Australia. In: Hobbs RJ, Suding K (ed) New models for ecosystem dynamics and restoration. Island Press, Washington DC, USA, pp 280-294

Grant CD, Campbell CJ, Charnock NR (2002) Selection of species suitable for derelict mine site rehabilitation in New South Wales, Australia. Water Air Soil Pollut 139:215-235

Grant CD, Norman MA, Smith MA (2007) Fire and silvicultural management of restored bauxite mines in Western Australia. Restor Ecol 15(Suppl):S127-S136

Gravina A, McKenna P, Glenn V (2011) Evaluating the success of mineral sand mine rehabilitation on North Stradbroke Island, Queensland: comparisons with reference eucalypt communities. Proc R Soc Qld 117:419-435

Guisan A, Zimmermann NE (2000) Predictive habitat distribution models in ecology. Ecol Model 135:147-186

Hallett LM, Standish RJ, Hulvey KB, Gardener MR, Suding KN, Starzomski BM, Murphy SD, Harris JA (2013) Towards a conceptual framework for novel ecosystems. In: Hobbs RJ, Higgs ES, Hall CM (ed) Novel ecosystems: intervening in the new ecological world order. Wiley \& Sons, Chichester, pp 16-28

Harris JA, Hobbs RJ, Higgs E, Aronson J (2006) Ecological restoration and global climate change. Restor Ecol 14:170-176

Herath DN, Lamont BB, Enright NJ, Miller BP (2009) Comparison of post-mine and natural shrubland communities in south-western Australia. Restor Ecol 17:577-585

Hobbs RJ (2004) Restoration ecology: the challenge of social values and expectations. Front Ecol Environ 2:43-48

Hobbs RJ, Norton DA (1996) Towards a conceptual framework for restoration ecology. Restor Ecol 4:93-110

Hobbs RJ, Suding K (ed) (2009) New models for ecosystem dynamics and restoration. Island Press, Washington DC, USA

Hobbs RJ, Arico S, Aronson J, Baron JS, Bridgewater P, Cramer VA, Epstein PR, Ewel JJ, Klink CA, Lugo AE, Norton D, Ojima D, Richardson DM, Sanderson EW, Valladares F, Vila M, Zamora R, Zobel M (2006) Novel ecosystems: 
theoretical and management aspects of the new ecological world order. Global Ecol Biogeogr 15:1-7

Hobbs RJ, Higgs E, Harris JA (2009) Novel ecosystems: implications for conservation and restoration. Trends Ecol Evol 24:599-605

Hobbs RJ, Higgs ES, Hall CM (ed) (2013) Novel ecosystems: intervening in the new ecological world order. John Wiley \& Sons, Chichester

Huxtable CHA, Koen TB, Waterhouse D (2005) Establishment of native and exotic grasses on mine waste overburden and topsoil in the Hunter Valley, New South Wales. Rangeland J 27:73-85

Jackson ST, Hobbs RJ (2009) Ecological restoration in the light of ecological history. Science 325:567-569

Koch JM (2007) Alcoa's mining and restoration process in south Western Australia. Restor Ecol 15(suppl):S11-S16

Madsen PA, Mulligan DR (2006) Effect of $\mathrm{NaCl}$ on emergence and growth of a range of provenances of Eucalyptus citriodora, Eucalyptus populnea Eucalyptus camaldulensis and Acacia salicina. Forest Ecol Manag 228:152-159

Majer JD, Heterick B, Gohr T, Hughes E, Mounsher L, Grigg A, et al. (2013) Is thirty-seven years sufficient for full return of the ant biota following restoration? Ecol Process 2:19

Mascaro J, Harris JA, Lach L, Thompson A, Perring MP, Richardson DM, Ellis E (2013) Origins of the novel ecosystems concept. In: Hobbs RJ, Higgs ES, Hall CM (ed) Novel ecosystems: intervening in the new ecological world order. Wiley \& Sons, Chichester, pp 45-57

Menzies NW, Mulligan DR (2000) Vegetation dieback on clay-capped pyritic mine waste. J Environ Qual 29:437-442

Mulligan D (ed) (1996) Environmental management in the Australian minerals and energy industries: principles and practices. University of New South Wales Press, Sydney

Neldner VJ, Wilson BA, Thompson EJ, Dillewaard HA (2012) Methodology for survey and mapping of regional ecosystems and vegetation communities in Queensland, version 3.2. Queensland Herbarium, Queensland Department of Science, Information Technology, Innovation and the Arts, Brisbane

Nichols OG, Nichols FM (2003) Long-term trends in faunal recolonization after bauxite mining in the jarrah forest of southwestern Australia. Restor Ecol 11:261-272

Norman MA, Koch JM, Grant CD, Morald TK, Ward SC (2006) Vegetation succession after bauxite mining in Western Australia. Vegetatio 43:5-21

Perring MP, Standish RJ, Hobbs RJ (2013) Incorporating novelty and novel ecosystems into restoration planning and practice in the 21st century. Ecol Process 2:18

Pokhrel LR, Dubey B (2012) Global scenarios for metal mining, environmental repercussions, public policies, and sustainability: a review. Crit Rev Environ Sci Technol. doi:10.1080/10643389.2012.672086

Queensland DEHP (2012) Rehabilitation requirements for mining projects. EM1122 version 1. Queensland Department of Environment and Heritage Protection, Brisbane

Sattler PS, Williams RD (ed) (1999) The conservation status of Queensland's bioregional ecosystems. Environmental Protection Agency, Brisbane

Schmidt S, Stewart GR, Ashwath N (1999) Monitoring plant physiological characteristics to evaluate mine site revegetation: a case study from the wetdry tropics of northern Australia. Plant Soil 215:73-84

Schneider A, Baumgartl T, Doley D, Mulligan D (2010) Evaluation of the heterogeneity of constructed landforms for rehabilitation using lysimeters. Vadose Zone J 9:898-909

Seastedt TR, Hobbs RJ, Suding KN (2008) Management of novel ecosystems: are novel approaches required? Front Ecol Environ 6:547-553

Shackelford N, Hobbs RJ, Heller NE, Hallett LM, Seastedt TR (2013a) Finding a middle-ground: the native/non-native debate. Biol Conserv 158:55-62

Shackelford N, Hobbs RJ, Burgar JM, Erickson TE, Fontaine JB, Laliberté EL, Ramalho CE, Perring MP, Standish RJ (2013b) Primed for change: developing ecological restoration for the 21st century. Restor Ecol 21:297-304

Smith P, Nichols O (2011) Development and assessment of rehabilitation criteria for high dune mineral sand mining on North Stradbroke Island. Proc R Soc Old 117:347-363

Suding KN, Hobbs RJ (2009) Threshold models in restoration and conservation: a developing framework. Trends Ecol Evol 24:271-279

Temperton VK, Hobbs RJ, Nuttle T, Halle S (2004) Assembly Rules and Restoration Ecology: Bridging the Gap between Theory and Practice. Island Press, Washington, DC
Tongway DJ, Ludwig JA (2011) Restoring disturbed landscapes: putting principles into practice. Island Press, Washington, DC

Tozer MG, Mackenzie BDE, Simpson CC (2012) An application of plant functional types for predicting restoration outcomes. Restor Ecol 20:730-739

Vickers H, Gillespie M, Gravina A (2012) Assessing the development of rehabilitated grasslands on post-mined landforms in north west Queensland, Australia. Agric Ecosys Environ 163:72-84

Wagner M (2004) The roles of seed dispersal ability and seedling salt tolerance in community assembly of a severely degraded site. In: Temperton VM, Hobbs RJ, Nuttle T, Halle S (ed) Assembly rules and restoration ecology. Island Press, Washington, DC, USA, pp 266-284

Warhurst A, Noromba L (2010) Corporate strategy and viable future land use: planning for closure from the outset of mining. Nat Res Forum 24:153-164

Williams ER, Mulligan DR, Erskine PD, Plowman KP (2012) Using insect diversity for determining land restoration development: examining the influence of grazing history on ant assemblages in rehabilitated pasture. Agric Ecosys Environ 163:54-60

Worrall R, Neil D, Brereton D, Mulligan D (2009) Towards a sustainability criteria and indicators framework for legacy mined land. J Cleaner Prod 17:1426-1434

doi:10.1186/2192-1709-2-22

Cite this article as: Doley and Audet: Adopting novel ecosystems as suitable rehabilitation alternatives for former mine sites. Ecological Processes 2013 2:22.

\section{Submit your manuscript to a SpringerOpen ${ }^{\circ}$ journal and benefit from:}

- Convenient online submission

Rigorous peer review

- Immediate publication on acceptance

- Open access: articles freely available online

- High visibility within the field

- Retaining the copyright to your article

Submit your next manuscript at $\mathbf{s p r i n g e r o p e n . c o m ~}$ 